\title{
The use of rural areas in Portugal: Historical perspective and the new trends
}

\author{
Maria Antónia Almeida* \\ Centre for Research and Studies in Sociology (ISCTE) - Lisbon University Institute - Portugal
}

Received: 15 April 2020 / Accepted: 9 August 2020

\begin{abstract}
The Portuguese landscape and its rural areas are the result of thousands of years of human presence, particularly since the late nineteenth century, when protectionist public policies were put in place to promote food self-sufficiency. During the Estado Novo regime, four main agricultural policies were enforced: wheat campaigns, internal colonization, agricultural hydraulic systems and reforestation. Nevertheless, there was a massive rural exodus, starting mainly in the 1960s, which resulted in the depopulation of 80 per cent of the territory. Nowadays, less than 20 per cent of the Portuguese population inhabits interior regions. This demographic change presents huge socio-economic challenges. Recently there have been new trends, based on land concentration and super intensive monoculture, which are incompatible with central and local governments' policies and strategies to reverse depopulation. The sustainability of Portugal's rural world, its landscape and the quality of life of its population are at risk. Four items were identified in this article: eucalyptus and pine forests, olive plantations, greenhouses and mining.
\end{abstract}

\section{Keywords}

Territories / History / Landscape / Public policies / Monoculture.

\section{O uso das zonas rurais en Portugal: perspectiva histórica e novas tendencias}

\section{Resumo}

A paisaxe portuguesa e as súas zonas rurais son o resultado de miles de anos de presenza humana, sobre todo desde finais do século XIX, cando se puxeron en marcha políticas públicas proteccionistas para garantir a autosuficiencia alimentaria. Durante o réxime do Estado Novo, aplicáronse catro políticas agrícolas principais: campañas de trigo, colonización interna, hidráulica-agrícola e forestación. Con todo, produciuse un éxodo rural masivo desde os anos sesenta, o que provocou o despoboamento do $80 \%$ do territorio, onde vive menos do $20 \%$ da poboación, un cambio demográfico que presenta enormes desafíos socioeconómicos. Recentemente, hai novas tendencias, baseadas na concentración da terra e no monocultivo superintensivo, que son incompatibles coas políticas e estratexias dos gobernos centrais e locais para reverter o despoboamento. A sostibilidade do mundo rural de Portugal, a súa paisaxe e a calidade de vida da súa poboación están en perigo. Identificáronse catro ítems: bosques de eucaliptos e piñeiros, oliveirais, invernadoiros e minaría.

Palabras clave

Territorios / Historia / Paisaxe / Políticas públicas / Monocultivo.

Códigos JEL: B11, Q15, R11.

\section{Introduction}

Landscape is a social construction built upon a natural and material basis. It is a concept materially and immaterially produced by culture (Maderuelo, 2005; Nogué, 2007) and a repository of heritage (Queiroz, 2009). Portuguese landscapes are vary greatly from north to south and from inland to coastline: there is everything from highlands to plains. Just like the "English Landscape", described by

* Corresponding author: mafpa@iscte-iul.pt 
Hoskins (1985), they have resulted from thousands of years of human presence, where several layers of interventions may be observed. There are dolmens and cromlechs all over the countryside, as well as Roman roads and bridges. There are mountain terraces, which are cuts in the terrain to sustain land for agriculture that create flat surfaces in otherwise steep hills (Lourenço, 2006). Particularly, since the late nineteenth century, when protectionist public policies were put in place to promote food selfsufficiency, rural areas have changed for good (Santos, 2017). The term rural is used for territories where people live in villages of small dimensions, with less than two thousand inhabitants, and the agricultural and forestry territories nearby (Baptista, 2018). During the Estado Novo regime in Portugal, four main agricultural policies were enforced in order to stimulate industrialization, while maintaining people in rural areas: wheat campaigns, internal colonization, implementation of agricultural hydraulic systems and reforestation. The Revolution of April 25th 1974 was followed by a transitional period which included an agrarian reform which, again, tried to increase jobs in agriculture and enforced a collective land process (Almeida, 2007).

Nevertheless, there was a massive rural exodus starting in the 1960s, which resulted in a depopulation of 80 per cent of the territory. Nowadays, less than 20 per cent of the Portuguese population inhabits interior regions. This demographic change presents huge socio-economic challenges.

Since this exodus, agriculture has no longer been the main activity, and new forms of occupation in rural areas have arisen. From rural tourism to promotion of heritage, both material and natural, many public policies have been put in place in order to attract people, families and private companies to rural territories (Almeida, 2018), where demographics will certainly not recover to the levels of mid-twentieth century. Local government is a key player in providing services and possibilities for a better quality of life for the remaining few who still resist the attraction of urban life.

Recently, there has been a

New wave of agricultural intensification in response to food security concerns associated with a fast-expanding global population as well as social inequality (...) promoted by a set of actors (e.g. food traders and retailers, producers of seeds, fertilizers, pesticides and herbicides, insurance companies, investment funds) with mutually reinforcing interests on global free trade of agricultural goods and related products, visible, for example, in the production of soybeans, corn and, more importantly for the Portuguese context, olive oil (Silveira, 2019, pp. 190 and 192).

In this context of globalization, there are new trends in Portuguese rural territories, particularly in the southern region of Alentejo, based on land concentration on a much larger scale than traditional latifundia and even collective land units of the agrarian reform, which are incompatible with strategies to reverse depopulation. There has also been an expansion of super intensive monoculture, with excessive use of water, synthetic chemicals and technology. Four items were identified, which may lead to the desertification of the land and have placed human lives at risk: in central and northern regions of Portugal there are eucalyptus and pine forests, which result in extensive fires, and mining; in the south there are super intensive olive tree plantations and greenhouses of different berries, which have transformed rural and human landscape, partially destroying the Montado.

This research was based on direct observation, specialised bibliography, political manifestos both from central and local government, and present discussions in the media and in parliament. The aim is to assign responsibilities for the quality of life of the rural population, particularly regarding sustainability of the Portuguese rural world and its landscape.

The conclusion is that rural residents are being ignored by the government. Urban concentration denies citizenship to people who live elsewhere, as well as most of their basic rights. Politicians have imposed the use of the word "citizens" to identify people of a country, thereby forgetting the rest of the population that lives in rural areas (Llamazares, 2017). Consequently, people who inhabit the rural world are unimportant, they do not count for votes, neither for protection nor services. Public policies for the rural world are insufficient and hard to enforce. They are contradicted by the deregulation of 
economic practices enforced by large companies. Solutions must be revised in order to increase the efficiency of the public policies and to promote the well-being of rural territories and their inhabitants, particularly regarding agricultural diversification and inspection resource use.

\section{Historical framework of Portugal's rural world}

The Portuguese rural world has a long history of being required to supply food to urban centres, without ever complying. This is because, among other factors, there were never enough people for agricultural labour. As a result of the fourteenth century crisis, with famine, plague and war, military defence and food self-sufficiency were the reasoning for state policies and laws to keep farmers on their lands in a country that was fighting for autonomy and independence (Almeida, 2016). As early as 1375, King Fernando issued a law to coerce people to stay on their lands and grow crops because of the lack of wheat and barley. It introduced the principle of land expropriation in case it was misused. Consequently, there was a growth in cultivated lands, but people kept abandoning the rural areas and Portugal was never self-sufficient in food supplies. This has been one of the main reasons for expanding Portuguese territory and conquering and discovering new lands since the fifteenth century. From the conquest of Ceuta in 1415 to finding the maritime route to India in 1498, wheat was a main concern, and trading spices for cereals from the north of Europe was an important feature of the international trade from the sixteenth century onwards.

The "Agrarian Question" was first put in writing by Father Manuel Severim de Faria in 1655: he described the lack of people in Alentejo as a problem which could be solved with the importation of African slaves, as well as dividing land and distributing it to people from the north, in order to supply cereals to the kingdom (Faria, 1740). In fact, throughout the sixteenth and seventeenth century, African slaves were brought to Portugal to work in agriculture, particularly in rice fields, because of their resistance to malaria. They also accounted for an important part of household servants and craftsmen and, in cities like Lisbon and Évora, 10 per cent of the population was African or of African descent (Fonseca, 2002, 2010).

Several eighteenth century physiocrat and mercantilist authors who were published in Memories of the Academy of Sciencies of Lisbon were Faria's followers. They presented solutions for increasing wheat production (Santos, 1993). Soares de Barros, the author who introduced demography in Portugal, wrote in 1789 that someday Alentejo should become Portugal's barn (Barros, 1990).

However, other than cereal production, traditional activities in rural Portugal were based on the Montado: a system which combines forest and pasture, with cork tree and holm oak woodlands, typical of the south-west Iberian Peninsula. Holm oaks provide firewood, coal, and acorn to feed the swine. Most importantly, cork trees supply cork for an industry which has been growing since the second half of the nineteenth century and has placed Portugal as a worldwide leader in the cork business (Faísca, 2019). Hunting was also an important activity in the Montado, both for the élite as a sport and for lower classes as a source of protein. Fire prevention is another example of an important regulating service provided by well-managed Montados, because cork trees don't perish by fire (the external layer of cork protects the tree).

As a complement to Montado, there have always been cereal crops, both for human and animal consumption, vegetable and fruit gardens in towns and farm headquarters, olive trees for olive oil, vines for wine production, cattle herds of swine, sheep, goats and some cows for meat, milk and cheese, as well as small farm animals: chickens, rabbits, even bees for honey, all described as assets in farmers' wills and estate inventories (Almeida, 2013). Important agriculturally-based industries have developed in rural areas since the eighteenth century, mainly wool and linen textiles, tanneries, crockeries, mills and soap factories (Matos, 1991); and, in the second half of the twentieth century, tomato and milk transformation plants, following a huge public investment in hydroelectric dams for electricity production and agricultural irrigation. 
The Alentejo region had been described in the sixteenth century as a huge brushwood interspersed with a few towns and villages surrounded by small portions of farmland (Lobo, 1984). It was a hunting ground for hogs and wild boar (Marques, 1968), or a kingdom of shepherds and swineherds surviving on acorns and firewood, who, together with some coalmen, lived in a state of true barbarism (Poinsard, 1910).

Salazar returned to the theme of Alentejo as Portugal's barn when he wrote about the "cereal question" in 1916 (Salazar, 1997). In the same line as USA's President Franklin D. Roosevelt's New Deal and fascist regimes in Europe, it launched the motto for the Estado Novo's wheat campaigns. As food independence was an early goal of fascism,

The first mass mobilizations involved wheat engineered to take advantage of chemical fertilizers, potatoes resistant to late blight, and pigs that thrived on national produce (...) the 'back to the land' aspect of fascism should be understood as a modernist experiment involving geneticists and their organisms, mass propaganda and overgrown bureaucracy (Saraiva, 2016, p. 9).

Since the first wheat campaign in 1929, all sectors of the nation's economic life have been involved in what was supposed to be a national mission to produce wheat, accompanied by elaborate propaganda to promote agriculture and to encourage people to work the fields. Its main features were credit for farmers and fixed price for selling the cereal (Baptista, 1996). The need for technology (farm machines and synthetic chemical fertilizers) resulted in industrial development: its greatest beneficiaries were metalworking and chemical industries (Cabral, 1974; Pais, 1999). It also contributed to the increase of the economic and social strength of landowners. Regarding labour, there were not enough local workers. Therefore, migrants were brought from northern regions and salaries were reduced to half (Pais, Lima, Baptista, Jesus \& Gameiro, 1976, 1978). Seasonal workers lived in the worst possible conditions, they were despised by locals and were called little mice (Almeida, 2002).

Wheat production increased, with the use of the best and most productive varieties. This caused genetic erosion: in 1920 there were thirty wheat varieties in Portugal; by 1970 only three survived. However, even with all the technology, soil conditions were not appropriate for wheat production and there was rapid soil erosion. The model had failed.

In 1938, a national plan for reforestation, led and financed by the State, was enforced in order to create economic benefits for the industrial sector and to contribute to fixating population in rural territories. It lasted until 1972 and it covered 318 thousand hectares (318,000 ha), with a completion rate of 76 per cent (Branco, 2011). Maritime pine (Pinus pinaster) was planted in inland mountains and coastal areas of central and northern Portugal, allowing

The development of a set of associated industries that contributed greatly to the creation of jobs in rural areas, but also to the establishment of a new industrial sector in which Portugal was a world leader for decades, the resin (...). In recent years, maritime pine (Pinus pinaster), cork oak (Quercus suber), and eucalyptus (Eucalyptus globulus) are the most representative species, occupying around $75 \%$ of the forest area (Nunes, Meireles, Gomes \& Ribeiro, 2019, p. 361).

However, this project has also eliminated pastures in the north of Portugal. As a result, most small farmers, shepherds and an entire population who depended on goats and sheep and all their by-products were pushed away from rural areas towards the cities, where they became wage earners.

Within its plan for industrial promotion, the Estado Novo also built dams for agricultural irrigation and to produce electricity. Its goal was to modernise Alentejo's agriculture and to industrialise the south of Portugal (Portas, 1967). The three major dams existing at that time were Maranhão, Montargil (1958) and Santa Clara (1973). Maranhão's dam was inaugurated in 1958, it occupies about 2,000 ha and for the last six decades has been irrigating olive groves, tomato plantations, corn and rice over $124 \mathrm{~km}$, as well as producing electricity for rural industries and villages. 
These projects in rural areas, together with new factories and a construction boom in the outskirts of Lisbon and Oporto attracted, and still do, most agricultural labour workers to new jobs in urban areas, with better wages and access to more satisfying living conditions, including education, health and job stability. Rural exodus was accompanied by emigration to other European countries, particularly France, Luxemburg, Switzerland and Germany, where over a million Portuguese people helped rebuild these countries after World War II, staying there afterwards. The Colonial War was also an important factor for emigration.

By the end of the decade, with a new President of the Council, Marcelo Caetano, who replaced Salazar in 1968, some social benefits and welfare laws were introduced to agricultural labour, as wages also rose. There was an effective mechanization of agriculture and a new class of entrepreneurs thrived: farm machine renters and tomato croppers (Almeida \& Martins, 2002). However, Portugal's rural society was still subject to an extreme income gap, as well as social and economic discrimination and inequality.

Immediately after the 1974 Revolution, concepts such as promotion of agriculture and gradual reform of the agrarian structure were introduced by the Movement of the Armed Forces program. It was the beginning of a complex legislative process that produced an agrarian reform in southern Portugal. Several laws were issued by provisory governments which resumed the themes of food self-sufficiency. Local citizen committees affiliated to the communist party led a people's movement; which put these laws into practice and occupied over one million hectares of land. Agrarian reform seized all large estates and created collective production units, in line with the Soviet model, to manage them on an intensive agriculture model based on cereals and cattle (this process was reversed a few years later and lands were returned to previous owners). Production and productivity levels did not go up during those years. Oil and wine production became almost non-existent, and cork, the region's biggest wealth, was stolen by corrupt industrialists. Salaries remained the same as before, even if, temporarily, there was job stabilization and lower unemployment. Just as in the nineteen thirties, wheat was not the best choice for the region and in 1979 there was a reduction on cereal production area.

With Portugal's integration in the European Union in 1986, several changes were inserted in the legislation in order to adapt Portuguese agriculture to European standards. With the Common Agricultural Policy, Portuguese farmers were encouraged to intensify, modernise and diversify their agricultural activities, and to combine the production of raw materials with hunting, fishing and pasture in an integrated economy scheme (Almeida, 2013). However, many were paid to set aside lands and stop production, which, again, drove away people from the countryside and traditional agriculture was mostly abandoned, remaining, at present, as only a complement to situations of leisure or poverty and with no impact on the economy. Moreover, the emergence of new activities, such as a new construction boom in urban areas, increased the rural exodus in the 1980s. The lack of labour for forestry activities led to the abandonment of forest land and to an increase in the seasonal rural fires (Nunes et al., 2019, p. 361). However, it was not until the construction of the Alqueva dam that intensive capitalist agriculture based on exhaustive irrigation changed the face of production in the Alentejo region.

\section{Rural depopulation and increasing territorial inequalities}

There are extreme contrasts in Portugal's demographic panorama, particularly between urban and rural spaces, and between the coastline and the depopulated interior. From 1960 to 1970 Portugal's rural world lost a third of its population to big cities, where industry was growing. Municipalities ranged from over half a million people in Lisbon in 2011 (in 1960, Portugal's capital had over 800,000 inhabitants) to 430 people in a small village in the Azores Islands. By comparing the last 2011 census to the one from 1960, 53 municipalities, which had a low demographic density to start with, lost over 50 per cent of their population, all of them in inland regions of Portugal. 
By 2015, 164 municipalities were considered in need of special care because of their low population density. In 1960, 35.2 per cent of the population lived in these municipalities; according to the 2011 census, only 19.7 per cent now live in these areas. Due to this dramatic reduction in population, these municipalities have completely lost their demographic and economic vitality (Almeida, 2018). On the other hand, as Lisbon was losing 31.7 per cent of its population and Oporto 21.7, their suburban areas were growing considerably, as well as other industrial towns.

With depopulation comes aging populations. In Alentejo, for every hundred young people there is an average 186.5 elderly. In some municipalities the average reaches 379 elderly. In some rural interior municipalities, for example in Pampilhosa da Serra, there were 4,100 young people in 1960 and in 2011 there were only 321.

Depopulation has been the main concern for local governments, as observed in political manifestos and messages. Municipalities' websites reveal attraction strategies for people and job creation, enhancing territories, heritage, landscape, environment, gastronomy (Almeida, 2017). They sell an image of rural areas as places of heritage conservation and excellent local products, with unique features, inherited from the concept of demarcated areas, created by the Marquis of Pombal in the eighteenth century for the Douro river and the production of Port Wine, and later copied by the Champagne region with the creation of the appellation d'origine contrôlée (AOC) in 1935. Their goal is to add value to local products, associating them to terroir, defined as "a concept almost untranslatable, combining soil, weather, region and notions of authenticity, of genuineness and particularity -of roots, and home- in contrast to globalized products designed to taste the same everywhere" (Allegra, 2019). Branding and certifications, both local and national, are important parts of that strategy. Some rural areas have benefited from this trend, achieving UNESCO Heritage certifications for their products (Almeida, 2017).

\section{New uses of rural areas and sustainability}

Rural depopulation has weakened interior territories' social, economic and political significance bowing to the loss of their productive role and active population. People are unprotected, alone, with restricted access to civil services, communications and security, particularly since public policies by the Social Democrat Government between 2011 and 2015, based on austerity policies and economic rationalization imposed upon Portugal by the European Union, have resulted in closing down health facilities, schools, courthouses, civil parishes (from 4,260 to 3,092) and post offices (in 2020 there are still 27 municipalities without them, even with government rules to have at least one in each municipality). Some examples of the poor conditions in the interior areas are as follows: telephone and internet coverage is generally weak, as well as communication between authorities in matters of fire prevention, as observed in the 2017 fires. Portugal is also a very centralized country, one of the most centralized in the OECD, considering it uses only 10 per cent of total public expense for local government. Half of public expense goes to Lisbon's Metropolitan Area, whose residents possess double the purchasing power of the rest of the territory (Azevedo, 2020).

Besides, for some urban groups, descendants of those who escaped misery and hard labour in agriculture, rural regions still present negative images related to sad memories, hunger, disease, a place their grandparents left for a better life (Almeida, 2010). For the "true modern", land is something they have "outgrown" (Leopold, 1949). And "rustic" is a social status from which people struggle to escape (Hespanha, 2018). In contrast to the English gentleman farmer or the proud French paysan, in Portugal. agriculture is not attractive and it is no longer the main activity in rural areas. With an aging population and a shortage of young people, the tertiary sector is now the most important one in interior regions, and, in many cases, municipalities are the largest employer.

Agrarian landscape has mostly been transformed into leisure space or into places of nature conservation, mainly associated with tourism (Eusébio, Carneiro, Kastenholz, Figueiredo \& Silva, 2017). People visit these areas to consume the unpolluted air, natural resources, tradition and heritage 
(Carneiro, Silva, Brandão \& Figueiredo, 2015, Silva, Figueiredo, Eusébio \& Carneiro, 2016), however broad its definition may be (Silva, 2008). The utilitarian function of the rural world as a supplier of food and raw material has been replaced by "theme parks" for alternative lifestyles. There has been a reconfiguration process in remote rural territories, which are currently facing new challenges and opportunities. Tourism and heritage have provided new roles and uses to rural areas which depend on urban society (Carvalho \& Correia, 2009). These post-agricultural spaces are suffering "McRuralisation" processes of globalization, with uses associated with consumption by new actors (visitors, tourists and environmentalists), sometimes neglecting local inhabitants' needs and desires, making them irrelevant (Figueiredo, 2013).

Even though the Brundtland Report established the concepts of "Sustainable Development" (World Commission on Environment and Development, 1987), capitalist logic has prevailed in rural areas throughout the world. In Portugal's rural world, three types of agriculture prevail: 1) highly competitive, specialized in fruits, wine and olive oil, fundamental for Portuguese exports, with low impact on local communities, low use of permanent labour, high use of seasonal labour; 2) based on cattle, corn and wheat, highly mechanized, with low use of labour, completely dependent on European subsidies; 3 ) social small size agriculture in urban gardens, a supplement to low pensions and unemployment, with some impact on community life and social relations (Baptista, 2006). The first two are mostly managed (and many owned) at a distance not by farmers but by international companies and investment funds with efficient technical teams of agronomists and economists. Therefore, rural populations are separated from agricultural activities in their territories. This type of agriculture is incompatible with the rural world because it does not use stable employment and does not observe labour laws, since it imports much cheaper illegal migrants.

A model of intensive monoculture, high on technology and synthetic chemicals and low on labour, using seasonal foreign workers, has been the solution for most farm managers in Alentejo, particularly since the construction of the Alqueva Dam. The construction of the Dam wnt through several phases: in 1975, the initial project designed the largest artificial lake in Western Europe for irrigation and to produce electricity, as well as complementary activities, such as tourism; in 1993 a new project emerged with governmental approval to start the construction; in 1996, the Portuguese Government decided to finance the project without European support; and, finally, in 2002 the dam was completed. The power plant for energy production was inaugurated in 2004 and the dam reached 91 per cent of its full capacity in 2010. The Alqueva Dam covers $250 \mathrm{~km}^{2}$ and irrigates 120,000 ha of corn, poppies (for the pharmaceutical industry), sunflowers, barley, vegetables, fruits (apples, citrus and table grapes, mostly for the northern European market) and almonds. However, olive tree plantations are the most important culture in the Alqueva irrigation perimeter: 41,000 ha, 57 per cent of the total area in 2016.

"In recent years, the olive oil produced in Portugal has achieved great success (because of the) growing appetite of European and world consumers for foods associated with the Mediterranean Diet", which caused the inclusion of these rural territories in the dynamics of globalization (Freire, 2017). The first large areas of intensive olive tree plantations were implemented by Spanish investors. Later, Portuguese companies also invested, and they now account for half of the olive oil production, exported mainly to Brazil, Italy and Spain (Empresa de Desenvolvimento e Infra-estruturas do Alqueva [Edia], 2017).

Landownership by the same families resisted over two centuries of regime transitions and even an agrarian reform (Almeida, 2013). Lately, their descendants have completely given up on agriculture and the largest estates have been sold out or rented long-term. In the last ten years, 70 per cent of lands in the Alqueva region have been sold, following an international trend for land grabbing, appropriation of resources and excessive use of water, synthetic chemicals and technology by international investment funds who control agricultural production and the international food trade. The "Agrifood" business is in the hands of a limited number of companies who also own agrochemicals and their distribution. They also practice "predatory pricing", avoiding market laws and competition (Khan, 2016). Corporate domain of agricultural systems has implications for justice and sustainability (Clapp \& Fuchs, 2009), as the companies deregulate markets and nations' authority. Nowadays, beneficiaries of the largest 
investment ever made in Portuguese agriculture are six companies run by foreigners, who own over 65 per cent of the region's olive tree plantations, which, in 2019, reached 56,500 ha (Barriga, 2020a).

This trend has also expanded to other irrigated areas, such as Maranhão, Montargil and Santa Clara dam regions, where centuries old montados have been replaced by olive tree plantations. On a property owned by a Spanish company, over a thousand oak trees were illegally removed to make room for olive trees (Dias, 2018). New plantations are highly mechanised, super intensive and use enormous amounts of water, pesticides and synthetic fertilizers (Figure 1), the negative impacts of which on soil have been known for decades. Specialists have long recommended their replacement with organic fertilizers (Heckman, 2006; Lipman, 1929). Watering super intensive monocultures in times of draught, such as the ones in the last few years, is inadequate. After six decades of fulfilling their irrigation purposes, these dams dried out in 2017 (Figure 2). As the draught continues, so does the irrigation of olive tree plantations.

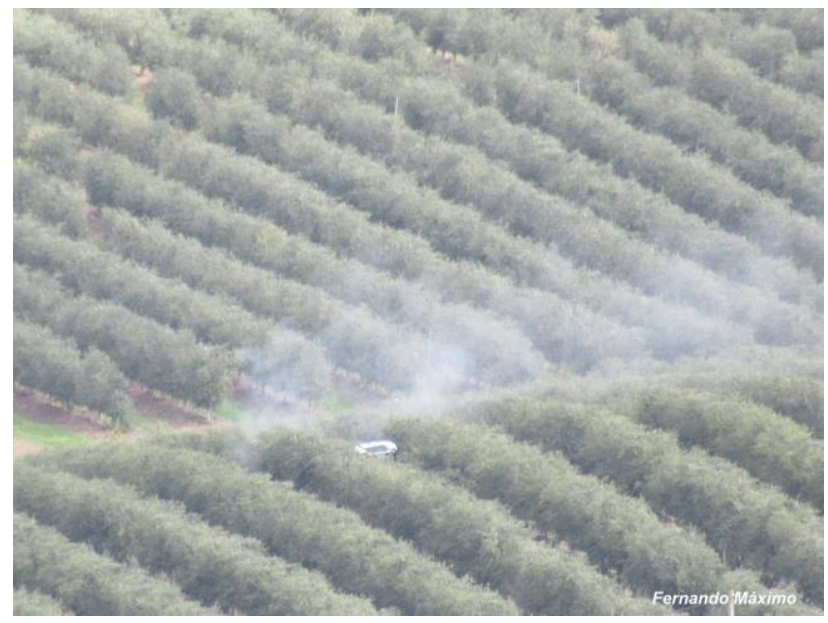

Figure 1. Applying chemicals in olive super intensive plantations, Avis, Alentejo, 2019. Source: Fernando Máximo, photographer.

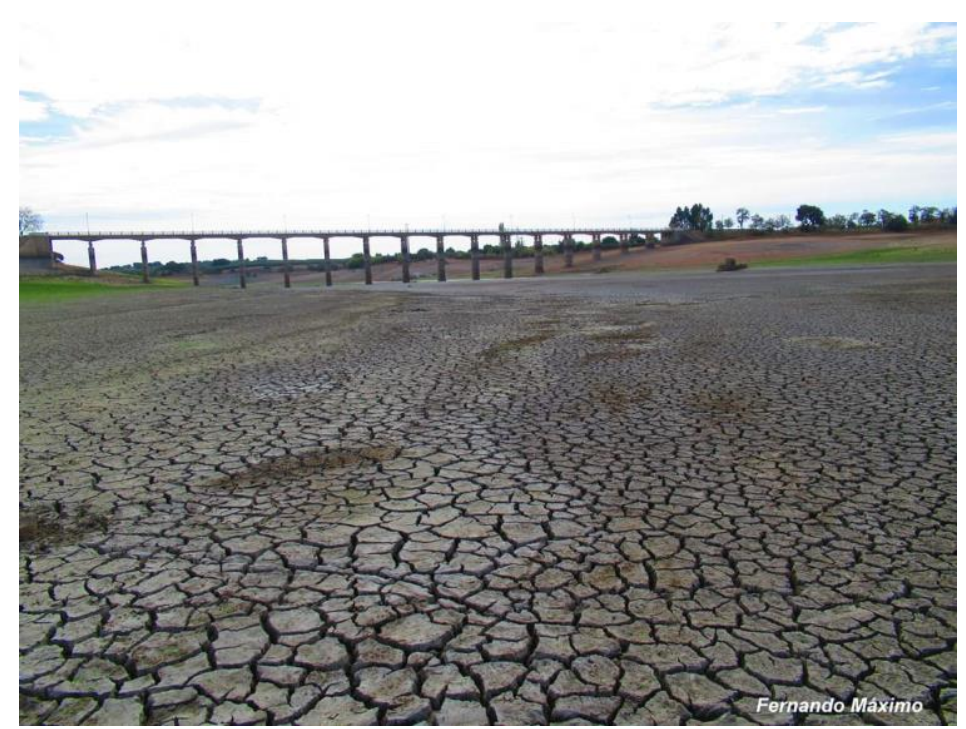

Figure 2: Maranhão Dam, Avis, Alentejo, July 2019. Source: Fernando Máximo, photographer. 
Large investments have been made and they are only viable for sizable estates, the dimensions of which exceed traditional latifundia in Portugal. Extensive scale investments and capital-intensive enterprises are features of "neoextractivism", which has been developed in Latin American economies since the beginning of the twentieth century because of the high prices of commodities, in a production intensive approach to development, or a "development illusion". This is a new socio-territorial model linked to monoculture, which eliminates other forms of production, damaging local and regional economies and driving people away (Svampa, 2019). In monoculture systems, water and land are all mobilized for the same product, wasting soils. For some authors it is considered ecocide (Barriga, $2020 \mathrm{~b}$ ), because it causes environmental danger, genetic erosion and the end of biodiversity. Traditional olive breeds are being replaced by a Spanish breed with less quality (Barriga, 2020c). With pesticides, most insects have been eliminated and with night olive harvests, birds are being killed in flocks. Both vertebrates (birds and bats) and invertebrates (insects) are natural plague regulators for olive trees, therefore olive tree plantations will most easily be affected, resulting in economic loss for the producers (Universidade de Évora, 2020).

This environmental issue includes extreme water, soil and air pollution caused by synthetic chemicals and fumes produced by mills. The problem of residue processing and disposal has grown exponentially, particularly regarding olive pomace (Barriga, 2020b). One example is the excessive use of plastics: there are 1,200 ha of greenhouses in Odemira by the Costa Vicentina Natural Park (Figure 3 ). Furthermore, in the Algarve, there is permanent irrigation of avocado plantations and golf courses, as well as the use of glyphosates (Viney, 2019). The Algarve's dams are also empty.

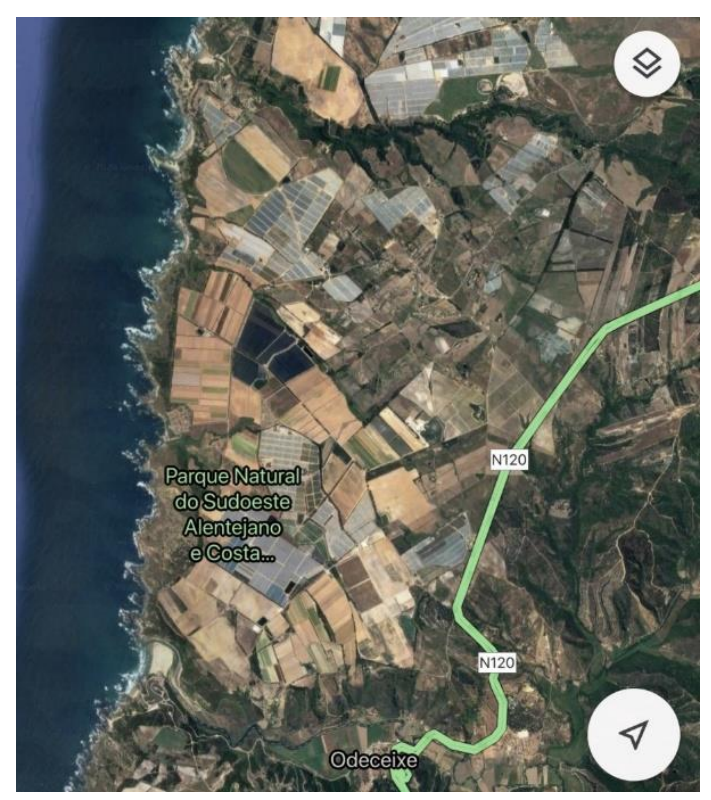

Figure 3: Greenhouses in Costa Vicentina Natural Park, on Alentejo Atlantic coast. Source: Visão, $27 / 01 / 2020$.

This new type of agriculture places our country in a similar situation to raw material dependent economies such as Brazil and Paraguay with its soya production (Pereira, 2016), or Mozambique with soya and sugarcane (Gomes, 2017), having negative impacts on local communities, as well as loss of sovereignty. In fact, Portugal is behaving as a colonial territory towards imperialist metropolises, a land for looting and plundering (Aráoz, 2013), particularly with olive tree and berry super intensive plantations which does not benefit local populations nor create jobs, because it uses seasonal labour, 
mostly illegal immigrants, following the California model, as other Mediterranean countries do (Corrado, Castro \& Perrotta, 2016), especially in the south of Spain with the African workers (Gertel \& Sippel, 2014; Hoggart \& Mendoza, 1999).

For some authors, and even for the Portuguese Government, this is a winning model, because it raises exports and produces positive economic results (Borralho, Pires \& Basílio, 2016). However, regarding labour and social progress, this is a step back in a country that has produced advanced labour and housing legislation in the last four decades of democracy. According to the International Labour Organization, forced labour includes various forms of debt bondage, human trafficking and working with living conditions contrary to human dignity, as well as restrictions on workers' freedom of movement, withholding of wages or identity documents, and threats of being reported to immigration authorities (International Labour Office [ILO], 2012).

Comparing to the little mice in the fields of Alentejo during wheat campaigns of the last century, the new super intensive olive tree plantations and berry greenhouses are colonial structures for exports which are raising the power of enslavement and racialisation machines (Bastos, 2019). In many cases, workers are hired through temporary labour companies who bring them from Nepal, Thailand, Pakistan, Eastern Europe and Africa with a promise of work and entrance in the European Union. They live in containers or in small overcrowded houses, since there are not enough available, in shocking conditions (according to the mayors) resembling slavery, victims of organizations who bring them from their countries and keep their passports and salaries. There are new villages of containers next to the properties' headquarters (Figure 4). In old villages there are people living in old houses, dozens in each small room with no conditions (Barriga, 2020c), which has created a violation of basic housing rights inscribed in the Portuguese Constitution (Guedes, 2018; Roseta, 2019).

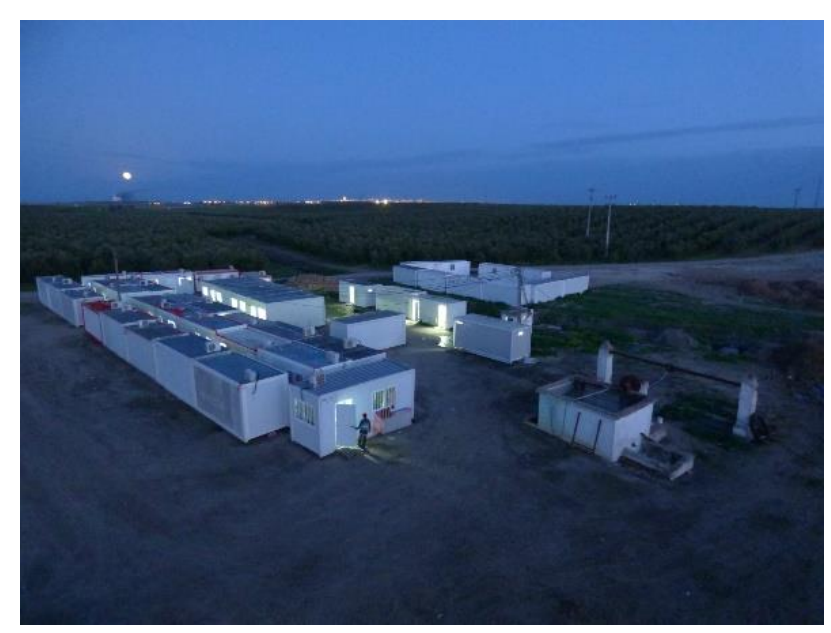

Figure 4: Containers in Alentejo. Source: Guedes (2018).

There is no accountability for landowners. Portuguese immigration and labour inspections are in short supply and, when they do proceed, they are usually too late, as these people have vanished. This is clearly human trafficking taking place in Portugal's rural world.

In Spain, this is also a massive problem, particularly in Andalusia. There have been racist incidents and election results show the rise of xenophobia towards migrant populations. Local governments have not been sensitive to the issue (Sampedro \& Camarero, 2018). On the other hand, in Alentejo's municipalities, special programs have been designed to welcome foreigners, helping their integration, language and social skills, particularly when they bring their families. There are success stories, with the help of local associations working together with local and central government agencies, such as Rota do Guadiana (http://www.rotaguadiana.org/) and Solidariedade Imigrante 
(http://www.solimigrante.org/). However, these agencies are distrusted by agricultural corporations, immigrants themselves and their intermediaries.

In small villages, the seasonal arrival of thousands of foreigners poses enormous challenges regarding housing, water and electrical supplies, security, medical staff, and schools. Odemira is an example of this situation. In a population of 26,000 , immigration has altered human and social geography of this municipality and caused a cultural shock: legal immigrants are now 5.000, 19 per cent of its population, composing of 68 different nationalities. During the harvesting season, immigrants increase exponentially to an estimated 25,000 workers, mostly men. In the Alqueva region, the village of Gasparões has had a sixfold population increase (Barriga, 2020 but new plantations have no effect on reducing unemployment, since they provide no jobs for locals. Alentejo still has a higher unemployment rate than the country's average: during the third trimester of 2019 it was 7 per cent, whereas Portugal's average was 6.1 per cent.

Regarding Portuguese forests, 2.6 per cent are state owned and 11 per cent are communal, managed by neighbour associations. 86 per cent of forest area is privately owned, divided mainly into medium and small sized properties, with an average 2,000 square meters each, many of them undivided for several generations and with a large percentage of heirs living abroad, after their parents and grandparent emigrated (Silva, Bica \& Soares, 2018). It is composed mostly of eucalyptus (26 per cent), followed by cork and pine trees (23 per cent each). Forest fires are directly related to depopulation and lack of economic activity in rural areas. Without people to live by, work in and use the forest, without animals to graze and wood to be picked up for fireplaces and cooking, wild bushes grow, and they are easily ignited by typically high temperatures in very dry summers. Other causes are the increase of continuous areas of forest with highly flammable materials (Canadas, Novais \& Marques, 2014). Territorial management, particularly in forestry areas, is marked by abandonment. Fires have had poor response from authorities and no previous planning (Camargo \& Castro, 2018).

On June 17th 2017, in Pedrógão Grande, over 450,000 ha burned: houses, industries and animals were destroyed, 250 people were wounded, and 65 human beings lost their lives (Elbein, 2019; Silva et al., 2018). Later, on October $15^{\text {th }}$ of the same year, over five hundred fires were declared at the same time, due to particularly windy and dry weather conditions, and another 45 people died. Arson was suspected and several people in charge of municipalities, fire departments and civil protection departments were prosecuted for inappropriate response to fires. This tragedy apparently had awakened Portuguese society and its elected representatives to the problem of forest fires. However, years have gone by and not much has been done to correct the situation, which may be repeated the following summers. The landscape is now filled with burnt trees and is completely abandoned (Figure $5)$.

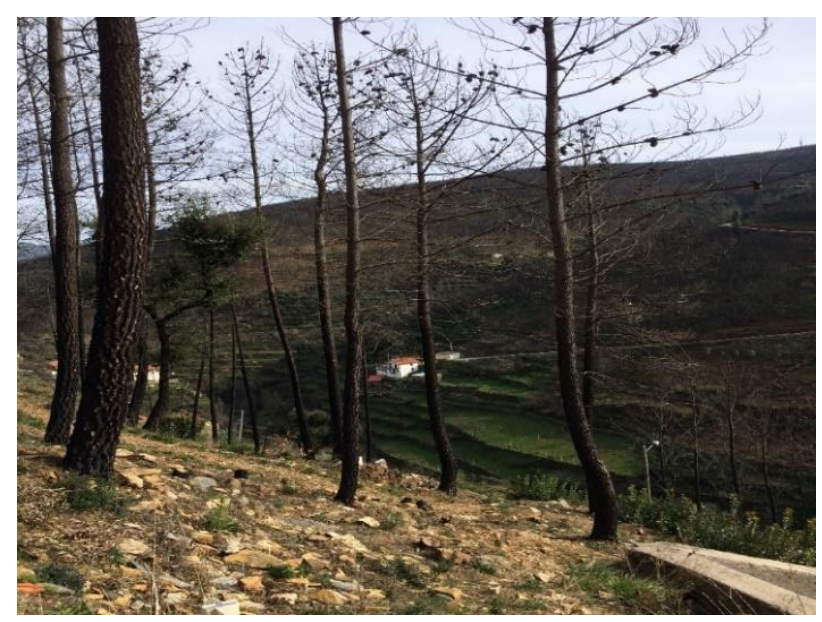

Figure 5: Burnt forests in Estrela mountain, on the road to Piódão. Source: author's photo. 
There will always be fires in Mediterranean ecosystems, but without territorial planning based on fiscal policies and high taxes, as well as adequate inheritance and real estate laws adjusted to the social function of properties, the situation will remain the same, aggravated by climate change and the prolongation and increase of the frequency of draughts (Amaral, 2018). Cooperative management solutions are also presented (Canadas et al., 2014), as well as heritage preservation and promotion of sustainable eco-tourism (Lourenço, 2006).

To worsen the devastation of the countryside, there are mining projects, including lithium extraction, in natural parks. Environmental and social impacts of mining for raw materials associated to renewable energies are toxic and harmful to local communities (Rodrigues, 2019). Local municipalities and associations are mobilizing to fight mining concessions to foreign companies willing to invest in their territories. The Portuguese Government has not been very sensitive to local populations' needs regarding this issue.

\section{Discussion}

There are direct relations between rural depopulation, fires, intensive monoculture and mining. In Portugal, public policies towards agriculture and forestry were planned and executed by agronomists, engineers and government officials of the Estado Novo. They were supposed to feed the people, create jobs and benefit the economy. Indeed, they have increased production, both in agriculture and industry. Dams were extremely important for industrialisation, for electricity production and water management for irrigation. Nevertheless, results are dubious, because of the inevitable rural exodus, soil, genetic erosion and forest fires. Nowadays, this new intensive agriculture is market-oriented and has no regard for the common good. It only profits big companies, who pay taxes elsewhere, with no benefits for the local economy nor its people. For the Portuguese Government, it counts as an increase of exports, but the seasonal labour and human trafficking it promotes is shameful in a country where there was a revolution and an agrarian reform whose goals included equal rights and pay for every worker. Human labour without minimum social conditions and integration into society devaluates the work of the democratic regime which was written into the 1976 Constitution.

Regarding fire prevention, new forms of soil management should be implemented to ensure a balance between the work done on private property with collective management of public territories. There is no proper fire prevention without the organisation of collective action of forest owners and the rural population (Mendes, Reis \& Louro, 2018).

This new type of agriculture, forest management and mining practices are incompatible with what is advertised for the rural world. Both local and central government programs and political manifestos have a discourse based on territorial development and cohesion (Almeida, 2018). Regardless of the way heritage, culture and local resources are sold as commodities to promote tourism, job creation and attraction strategies, companies and industries remain the most important feature for keeping people in interior regions. Seasonal activities such as rural tourism or festivals may be important, but they cannot solve a region's sustainability problems. Without permanent economic activities there is no way to reverse the demographic trend.

Natural heritage is the most important touristic resource that low-density territories have to offer. However, super intensive monoculture, greenhouses and fires have a drastic effect on the quality of tourist destinations (Simões, Nogueira \& Moreno, 2018).

Strong public intervention is required, and has already begun, not only in scientific conferences and articles, but also in the form of manifestos and press releases by scientists ${ }^{1}$. However, the Portuguese Government's programs for the rural world have been mostly reactive and have had limited results (Carvalho \& Simões, 2018). Local government could be a key player in reversing such situations.

1 Teresa Pinto-Correia, Mário de Carvalho, Ricardo Serralheiro, António Chambel, José Munoz-Rojas, Miguel Araújo, Rosário Partidário, Isabel Loupa Ramos, João Ferrão, "Sustentabilidade da agricultura no Alentejo em risco", Expresso, 21/07/2020. Retrieved from: https://expresso.pt/opiniao/2020-07-21-Sustentabilidade-da-agricultura-no-Alentejo-em-risco. 
Considering the importance of landscape and heritage for local economic and social lives, it is important that local governments realize their role in preserving these features under the best possible conditions. Tourists and travellers want to visit beautiful scenery and traditional agricultural fields, they want to see sheep grazing in green pastures, hunt in the wild, and they want to swim and practice water sports in clean waters. The rural world is advertised to city folks and foreigners as a place for good traditional food and wine, made with local, clean and unpolluted products.

Municipalities and parishes are the closest to all these problems and it is their responsibility to address them and provide the best answers for the people. As elected representatives, their job is to make sure irregularities are detected and denounced, as did Avis' Municipal Assembly, with its recent request for the intervention of the Regional Department of Agriculture, the Portuguese Agency for the Environment and the Tagus Hydrographic Region Administration on licencing and overseeing intensive plantations and their use of pesticides and fertilisers ${ }^{2}$. The quality of life of their citizens should be a priority, particularly health, security, jobs and social rights, regardless of the interests of big companies. Local actors should be mobilised in order to create new forms of civic intervention and territorial management, in a governance model which implies enabling local communities. State intervention cannot be limited to legislation, it must regulate and supervise its implementation (Simões et al., 2018).

Depopulation is a fact, not a fatality, and local development policies must promote models that are appropriate for low population densities (Baptista, 2010; Ferrão, 2018). It may be irreversible, along with soil desertification. Nonetheless, the few people who still inhabit interior regions have the same constitutional rights as urban residents. There is an urgent need for agricultural reconversion to traditional practices and the creation of a more sustainable model which provides permanent jobs for locals and contributes to renewing families' interests in the rural world. In order to encourage this change, quality services must be provided and public policies should be enforced to promote investments in cultural reconversion and reforesting with autochthone species such as cork trees and other Quercus species, more appropriate to the Mediterranean climate.

There is as yet no ethic dealing with man's relation to land and to the animals and plants which grow upon it. Land is still property (...) the evolutionary process for an ethic is simply this: quit thinking about decent land-use as solely an economic problem (Leopold, 1949, p. 203).

Until then, the economic recovery of Portugal's rural areas has a long road ahead.

\section{References}

Allegra, M. (2019). Se o vinho sabe bem... O Lado Negro do terroir. In J. Ferrão et al. (Eds.), Reflexões sobre Ambiente, Território e Sociedade: Três Anos do Blogue ATS (pp. 246-249). Lisboa, Portugal: Observa-Instituto de Ciências Sociais da Universidade de Lisboa. Retrieved from: https://repositorio.ul.pt/handle/10451/37011? mode=full

Almeida, M. (2002). Ratinho. In N. L. Madureira (Coord.), C. A. Martins \& N. G. Monteiro (Col.), História do Trabalho e das Ocupações, vol. III (pp. 247-252). Oeiras, Portugal: Celta.

Almeida, M. (2007). Memory and trauma of the Portuguese Agrarian Reform: A case study. Portuguese Journal of Social Science, 6(2), 63-76. DOI: https://doi.org/10.1386/pjss.6.2.63 1

Almeida, M. (2010). Memórias Alentejanas do Século XX. Cascais, Portugal: Princípia. DOI: https://doi.org/10.13140/RG.2.1.2428.4322

Almeida, M. (2013). Landlords, tenants and agrarian reform: Local elites and regime transitions in Avis, Portugal, 1778-2011. Rural History, 24(2), 127-142. DOI: https://doi.org/10.1017/S0956793313000046

Almeida, M. (2016). A Questão Agrária na História de Portugal. Mátria XXI, 5, 255-284. Retrieved from: https://repositorio.iscteiul.pt/bitstream/10071/12275/5/2016 A Questao Agraria na Historia de Portugal.pdf

2 Avis' Municipal Assembly "Pela Defesa do Direito ao Futuro do Nosso Território", 09/06/2020, http://www.cmavis.pt/index.php?option=com_content\&view=article\&id=2581:tomada-de-posicao-pela-defesa-do-direito-ao-futuro-donosso-territorio\&catid $=100 \&$ Itemid $=472$. 
Almeida, M. (2017). Territorial inequalities: Depopulation and local development policies in the Portuguese rural world. AGER - Revista de Estudios sobre Despoblación y Desarrollo Rural, 22, 61-87.

DOI: https://doi.org/10.4422/ager.2016.08

Almeida, M. (2018). Fighting depopulation in Portugal: Local and central government policies in times of crisis. Portuguese Journal of Social Science, 17(3), 289-309. DOI: https://doi.org/10.1386/pjss.17.3.289 1

Almeida, M., \& Martins, C. (2002). Alugador de máquinas. In N. L. Madureira (Coord. ), C. A. Martins \& N. G. Monteiro (Col.), História do Trabalho e das Ocupações, vol. III (pp. 285-288). Oeiras, Portugal: Celta.

Amaral, P. (2018). As políticas de solos e de ordenamento do território face aos fogos florestais. In O. Simões (Ed.), O rural depois do fogo (pp. 89-98). Coimbra, Portugal: ESAC/IPC.

Aráoz, H. (2013). Crisis ecológica, conflictos socioambientales y orden neocolonial. Las paradojas de Nuestra América en las fronteras del extractivismo. Revista Brasileira de Estudos Latino-Americanos, 3(1), $118-155$. Retrieved from: https://horizontescomunitarios.files.wordpress.com/2016/10/machado-araoz-crisisecolc3b3gica-conflictos-socioambientales-y-orden-neocolonial.pdf

Azevedo, C. (2020). Descentralizar o Estado para servir melhor. Brotéria, 190(1), 35-40.

Baptista, F. (1996). Política Agrária. In F. Rosas \& J. M. B. Brito (Eds.), Dicionário de História do Estado Novo, vol. II (pp. 749-754). Venda Nova, Portugal: Bertrand.

Baptista, F. (2006). O rural depois da agricultura. In M. L. Fonseca (Ed.), Desenvolvimento e território: espaços rurais pós-agrícolas e novos lugares de turismo e lazer (pp. 85-105). Lisboa, Portugal: Universidade de Lisboa, Centro de Estudos Geográficos.

Baptista, F. (2010). O espaço rural: declínio da agricultura. Lisboa, Portugal: Celta.

Baptista, F. (2018). Rural e floresta, caminhos por definir. In O. Simões (Ed.), O rural depois do fogo (pp. 45-60). Coimbra, Portugal: ESAC/IPC.

Barriga, P. (16 January, 2020a). Grande Investigação: Os novos donos do Alentejo. Sábado. Retrieved from: https://www.sabado.pt/portugal/detalhe/os-novos-donos-do-alentejo

Barriga, P. (23 January, 2020b). Grande Investigação: O lado negro do negócio dourado do azeite. Sábado. Retrieved from: https://www.sabado.pt/portugal/detalhe/grande-investigacao-o-lado-nego-do-negociodourado-do-azeite

Barriga, P. (3 February, 2020c). Grande Investigação: Os novos escravos do Alentejo. Sábado. Retrieved from: https://www.sabado.pt/portugal/detalhe/os-novos-escravos-do-alentejo

Barros, J. (1789-1815/1990). Memória sobre as causas da diferente população de Portugal em diversos tempos da monarquia. In J. L. Cardoso (Ed.), Colecção de Obras Clássicas do Pensamento Económico Portugués. Memórias económicas da Academia Real das Ciências de Lisboa, para o adiantamento da agricultura, das artes, e da indústria em Portugal e suas conquistas (1789-1815), t. I (pp. 99-117). Lisboa, Portugal: Banco de Portugal. Retrieved from: https://www.bportugal.pt/sites/default/files/ocpep-1_t1.pdf

Bastos, C. (2019). Açúcar, ananases e ilhéus portugueses no Hawaii: dinâmicas de migração, etnicidade e racialização no terreno e no arquivo. Etnográfica, 23(3), 777-798. DOI: https://doi.org/10.4000/etnografica.7674

Borralho, C., Pires, C., \& Basílio, M. (2016). Casos empresariais de sucesso no Baixo Alentejo e no Alentejo Litoral. Lisboa, Portugal: Chiado.

Branco, A. (2011). El Plan de Repoblación Forestal (1938-1968): una medida del Estado Novo por evaluar. In D. Lanero \& D. Freire (Eds.), Agriculturas e innovación tecnológica en la Península Ibérica (1946-1975) (pp. 135-166). Madrid: Ministerio de Medio Ambiente y Medio Rural y Marino.

DOI: https://doi.org/10.1016/j.ihe.2013.11.009

Cabral, M. (1974). Materiais para a História da Questão Agrária em Portugal, sécs. XIX e XX. Porto, Portugal: Inova.

Camargo, J., \& Castro, P. (2018). Portugal em chamas. Como resgatar as florestas. Lisboa, Portugal: Bertrand.

Canadas, M., Novais, A., \& Marques, M. (2014). Proprietários florestais, políticas e territórios Incêndios e a gestão do espaço rural. Venda do Pinheiro, Portugal: Animar.

Carneiro, M., Silva, D., Brandão, V., \& Figueiredo, E. (2015). Da Regulamentação à Promoção - o rural nos planos Nacionais de turismo (1985-2011). Revista de Economia e Sociologia Rural, 53(1), 9-22. DOI: https://doi.org/10.1590/1234-56781806-94790053s01001

Carvalho, P., \& Correia, J. (2009). Turismo, património(s) e desenvolvimento rural: a percepção local da mudança. In L. Moreno, M. M. Sánchez \& O. Simões (Coords.), Cultura, Inovação e Território: o Agroalimentar e o Rural (pp. 187-196). Lisboa, Portugal: SPER. Retrieved from: https://repositorio.ul.pt/bitstream/10451/38907/1/Moreno Sanchez Simoes 2009 acesso\%20aberto.pdf

Carvalho, P., \& Simões, O. (2018). Governança e políticas públicas. 0 processo de decisão política em sistemas complexos. In O. Simões (Ed.), O rural depois do fogo (pp. 23-44). Coimbra, Portugal: ESAC/IPC. 
Clapp, J., \& Fuchs, D. (2009). Agrifood corporations, global governance, and sustainability: A framework for analysis. In J. Clapp \& D. Fuchs (Eds.), Corporate power in global agrifood governance (pp. 1-25). Cambridge, MA: MIT Press.

Retrieved from: https://pdfs.semanticscholar.org/fcf4/8aea576b72df85250d69403b8f2d796c8113.pdf

Corrado, A., Castro, C., \& Perrotta, D. (Eds.). (2016). Migration and agriculture. Mobility and change in the Mediterranean area. London, England: Routledge. DOI: https://doi.org/10.4324/9781315659558

Dias, C. (30 October, 2018). Mais de um milhar de azinheiras arrancadas para dar lugar a olival intensivo. Público. Retrieved from: https://www.publico.pt/2018/10/30/sociedade/noticia/milhar-azinheiras-dao-lugarplantacao-olival-intensivo-norte-alentejano-1849392

Edia. (2017). Anuário Agrícola de Alqueva. Beja, Portugal: DEAPR, DPEA. Retrieved from: https://www.edia.pt/wpcontent/uploads/2019/05/Anuario_Agricola Alqueva 2017.pdf

Elbein, S. (6 December, 2019). How to live with mega-fires? Portugal's feral forests may hold the secret. National Geographic. Retrieved from: https://www.nationalgeographic.com/science/2019/12/how-to-live-withmega-fires-portugal-forests-may-hold-secret/

Eusébio, C., Carneiro, J., Kastenholz, E., Figueiredo, E., \& Silva, D. (2017). Who is consuming the countryside? An activity-based segmentation analysis of the domestic rural tourism market in Portugal. Journal of Hospitality and Tourism Management, 31, 197-210. DOI: https://doi.org/10.1016/j.jhtm.2016.12.006

Faísca, C. (2019). El negocio corchero en Alentejo: explotación forestal, industria y política económica, 1848-1914. (Tesis doctoral). Badajoz: Universidad de Extremadura.

Retrieved from: http://dehesa.unex.es/handle/10662/10257

Faria, M. (1655/1740). Noticias de Portugal. Lisboa, Portugal: Oficina de António Isidoro da Fonseca.

Ferrão, J. (2018). Despovoamento em áreas rurais: entre a inevitabilidade e a capacidade de transformação. Cultivar. Cadernos de Análise e Prospetiva, 11, 13-19.

Retrieved from: https://repositorio.ul.pt/handle/10451/33338

Figueiredo, E. (2013). McRural, No Rural or What Rural? - Some reflections on rural reconfiguration processes based on the promotion of Schist Villages Network, Portugal. In L. Silva \& E. Figueiredo (Eds.), Shaping rural areas in Europe. Perceptions and outcomes on the present and the future (pp. 129-146). Dordrecht, Netherlands: Springer. DOI: https://doi.org/10.1007/978-94-007-6796-6

Fonseca, J. (2002). Escravos no Sul de Portugal: Séculos XVI-XVII. Lisboa, Portugal: Vulgata.

Fonseca, J. (2010). Escravos e Senhores na Lisboa Quinhentista. Lisboa, Portugal: Colibri.

Freire, D. (2017). Changing the olive oil value chain: Food regime and development in Portugal: Global processes and local futures. In M. Miele., V. Higgins, H. Bjorkhaug \& M. Truninger (Eds.), Transforming the rural: Global processes and local futures (pp. 197-220). Bingley, England: Emerald.

Gertel, J., \& Sippel, S. (Eds.). (2014). Seasonal workers in Mediterranean agriculture. The social costs of eating fresh. London, England: Routledge.

Gomes, C. (2017). A justice approach to the African 'land rush': Investigating the social dynamics around agricultural investments in Mozambique. (PhD dissertation). Norwich, England: University of East Anglia. Retrieved from: https://ueaeprints.uea.ac.uk/id/eprint/66546/

Guedes, N. (8 February, 2018). A Fábrica da Azeitona. Reportagem TSF num Alentejo a mudar rapidamente. TSF Rádio Notícias. Retrieved from: https://www.tsf.pt/sociedade/a-fabrica-da-azeitona-reportagem-tsf-numalentejo-a-mudar-rapidamente-9105507.html

Heckman, J. (2006). A history of organic farming: Transitions from Sir Albert Howard's "War in the Soil" to USDA National Organic Program. Renewable Agriculture and Food Systems, 21(3), 143-150. DOI: https://doi.org/10.1079/RAF2005126

Hespanha, A. (2018). Categorias. Uma reflexão sobre a prática de classificar. Práticas da História, 7, $224-256$. Retrieved from: http://www.praticasdahistoria.pt/issues/2019/7/10_PDH07_Hespanha.pdf

Hoggart, K., \& Mendoza, C. (1999). African immigrant workers in Spanish agriculture. Sociologia Ruralis, 39(4), 538-562. DOI: https://doi.org/10.1111/1467-9523.00123

Hoskins W. (1955/1985). The making of the English landscape. New York, NY / London, England: Penguin.

ILO. (2012). General Survey on the fundamental Conventions concerning rights at work in light of the ILO Declaration on Social Justice for a Fair Globalization. Report III(1B): Giving Globalization a Human Face (General Survey on the Fundamental Conventions). Generva, Switzerland: International Labour Office. Retrieved from: https://www.ilo.org/wcmsp5/groups/public/---ed norm/--relconf/documents/meetingdocument/wcms 174846.pdf

Khan, L. (2016). Amazon's Antitrust Paradox. The Yale Law Journal, 126(3), 710-805. Retrieved from: https://www.yalelawjournal.org/note/amazons-antitrust-paradox 
Leopold, A. (1949). The Land Ethic. In A. Leopold, A Sand County almanac and sketches here and there (pp. 201-226). New York, NY / Oxford, England / New York, NY: Oxford University Press.

Lipman, J. (1929). The economic significance of commercial fertilizers. The Annals of the American Academy of Political and Social Science, 142, 257-265. DOI: https://doi.org/10.1177/000271622914200129

Llamazares, J. (10 March, 2017). La literatura de la España vacía. El País. Retrieved from: https://elpais.com/cultura/2017/03/10/babelia/1489139394 474583.html

Lobo, A. (1903/1984). História da sociedade em Portugal no século XV. Lisboa, Portugal: Rolim.

Lourenço, L. (2006). Paisagens de Socalcos e Riscos Naturais em vales do rio Alva. Coimbra, Portugal: Universidade de Coimbra, Facultade de Letras, Núcleo de Investigação Científica de Incêndios Florestais.

Maderuelo, J. (2005). El paisaje: genesis de un concepto. Madrid: Abada.

Marques, A. (1968). Introdução à História da Agricultura em Portugal. A questão cerealífera durante a Idade Média. Lisboa, Portugal: Cosmos.

Matos, A. (1991). A indústria no distrito de Évora, 1836-90. Análise Social, XXVI(112-113), 561-581. Retrieved from:http://dspace.uevora.pt/rdpc/bitstream/10174/2397/1/A\%20Ind\%C3\%BAstria\%20no\%20distrito\% 20de\%20\%C3\%89vora\%20-\%20An\%C3\%A1lise\%20Social.pdf

Mendes, A., Reis, J., \& Louro, V. (2018). 0 rural e a floresta, um ano depois do fogo. 0 que foi feito e o que ainda falta fazer... In O. Simões (Ed.), O rural depois do fogo (pp. 271-276). Coimbra, Portugal: ESAC/IPC.

Nogué, J. (Ed.). (2007). La construcción social del paisaje. Madrid: Biblioteca Nueva. Retrieved from: https://leerlaciudadblog.files.wordpress.com/2019/03/noguecc81-la-construcciocc81n-social-delpaisaje.pdf

Nunes, l., Meireles, C., Gomes, C., \& Ribeiro, N. (2019). Socioeconomic aspects of the forests in Portugal: Recent evolution and perspectives of sustainability of the resource. Forests, 10(5), 361. DOI: https://doi.org/10.3390/f10050361

Pais, J. (1999). Campanha do Trigo. In A. Barreto \& M. Mónica (Eds.), Dicionário de História de Portugal Suplemento A/E, vol. VII (pp. 227-229). Porto, Portugal: Figueirinhas.

Pais, J., Lima, A. I., Baptista, J., Jesus, M. F., \& Gameiro, M. M. (1976). Elementos para a história do fascismo nos campos: A “Campanha do Trigo": 1928-38 (I). Análise Social, XII(46), 400-474. Retrieved from: http://analisesocial.ics.ul.pt/documentos/1223914262J9lUY8mu3Ig96WV6.pdf

Pais, J., Lima, A. I., Baptista, J., Jesus, M. F., \& Gameiro, M. M. (1978). Elementos para a história do fascismo nos campos: A “Campanha do Trigo": 1928-38 (II). Análise Social, XIV(54), 321-389. Retrieved from: http://analisesocial.ics.ul.pt/documentos/1223989053Q5hNW8wm8Db11DB9.pdf

Pereira, L. (2016). Tudo para o capital transnacional: a apropriação de terras por estrangeiros no Paraguai. Geografia em Questão, 9(2), 107-125. Retrieved from: https://www.researchgate.net/publication/316666488 TUDO_PARA O CAPITAL_TRANSNACIONAL_A APRO PRIACAO DE TERRAS POR ESTRANGEIROS

Poinsard, L. (1910). Le Portugal inconnu. Paysans, marins et mineurs. Paris, France: Bureaux de la Science Sociale.

Portas, C. (1967). O Alentejo: situação e perspectivas sócio-económicas. Análise Social, V(18), 185-206. Retrieved from: http://analisesocial.ics.ul.pt/documentos/1224173616M9rYM9vb3Jp84JB3.pdf

Queiroz, A. (2009). A Paisagem de Terras do Demo. Lisboa, Portugal: Esfera do Caos.

Rodrigues, L. (18 July, 2019.) 0 mundo não será salvo por energias renováveis, Jornal I. Retrieved from: https://ionline.sapo.pt/artigo/665408/o-mundo-nao-sera-salvo-por-energias-renovaveis?seccao $=0$ pini $\%$ C $3 \%$ A3o

Roseta, H. (7 November, 2019). Os contentores de Odemira. Público. Retrieved from: https://www.publico.pt/2019/11/07/sociedade/opiniao/contentores-odemira-1892697

Salazar, A. (1997). Questão Cerealífera. O Trigo [1916]. In N. Valério (Ed.), O Ágio do Ouro e outros textos económicos 1916-1918 (pp. 149-220). Lisboa, Portugal: Banco de Portugal.

Sampedro, R., \& Camarero, L. (2018). Foreign immigrants in depopulated rural areas: Local social services and the construction of welcoming communities. Social Inclusion, 6(3), 337-346. DOI: http://dx.doi.org/10.17645/si.v6i3.1530

Santos, H. (2017). Portugal: paisagem rural. Lisboa, Portugal: Fundação Francisco Manuel dos Santos.

Santos, R. (1993). A nuvem por Juno? O tema da fisiocracia na historiografia do pensamento económico português. Análise Social, XXVIII(121), 423-443.

Saraiva, T. (2016). Fascist Pigs: Technoscientific organisms and the history of fascism. Cambridge, MA / London, England: The MIT Press. DOI: https://muse.jhu.edu/book/48402

Silva, D., Figueiredo, E., Eusébio, C., \& Carneiro, M. (2016). The countryside is worth a thousand words - Portuguese representations on rural areas. Journal of Rural Studies, 44, 77-88.

DOI: https://doi.org/10.1016/j.jrurstud.2016.01.012 
Silva, L. (2008). Contributo para o estudo da pós-ruralidade em Portugal. Arquivos da Memória, 4, 6-25. Retrieved from: http://arquivos-da-memoria.fcsh.unl.pt/ArtPDF/02 Luis Silva.pdf

Silva, M., Bica, M., \& Soares, P. (2018). Do abandono da pequena agricultura, ao drama dos incêndios rurais. In 0. Simões (Ed.), $O$ rural depois do fogo (pp. 61-72). Coimbra, Portugal: ESAC/IPC.

Silveira, A. (2019). Sustainable intensification of agriculture? Insights from water systems and an old oxymoron. In J. Ferrão et al. (Eds.), Reflexões sobre Ambiente, Território e Sociedade: Três Anos do Blogue ATS (pp. 188-193). Lisboa, Portugal: Observa-Instituto de Ciências Sociais da Universidade de Lisboa. Retrieved from: https://repositorio.ul.pt/handle/10451/37011? mode=full.

Simões, O., Nogueira, J., \& Moreno, L. (2018). Aprender a coexistir com o fogo. In O. Simões (Ed.), O rural depois do fogo (pp. 259-269). Coimbra, Portugal: ESAC/IPC.

Svampa, M. (2019). Las fronteras del neoextrativismo en America Latina. Conflictos socioambientales, giro ecoterritorial y nuevas dependencias. Guadalajara, Mexico: Universidad de Guadalajara. Retrieved from: http://calas.lat/sites/default/files/svampa neoextractivismo.pdf

Universidade de Évora. (28 February, 2020). Investigação da UÉ apresenta medidas para a gestão sustentável em olivais mediterrânicos. Notícias. Retrieved from: https://www.agroportal.pt/investigacao-da-ue-apresentamedidas-para-a-gestao-sustentavel-em-olivais-mediterranicos/

Viney, C. (18 October, 2019). Avocado monoculture wreaks havoc on Castro Marim Reserve, destroying UNESCOprotected ecosystem. algarvedailynews.com. Retrieved from: https://algarvedailynews.com/news/17198avocado-monoculture-wreaks-havoc-on-castro-marim-reserve-destroying-unesco-protected-ecosystem

World Commission on Environment and Development. (1987). Our common future. Oxford, England/ New York, NY: Oxford University Press.

Retrieved from: https://sustainabledevelopment.un.org/content/documents/5987our-common-future.pdf 